\title{
POTENSI DAN EKSISTENSI PRODUKSI GARAM KONSUMSI DI KABUPATEN PATI
}

\section{THE POTENTIAL AND EXISTING PRODUCTION OF CONSUMING SALT IN PATI REGENCY}

\author{
Suroso \\ Kantor Penelitian dan Pengembangan Kabupaten Pati \\ Email: suroso_peneliti@yahoo.co.id
}

Naskah Masuk: 23 Maret 2015 Naskah Revisi: 1 April $2015 \quad$ Naskah Diterima: 13 April 2015

\begin{abstract}
Pati Regency has a great potential production of consuming salt but there is an indication that the existing production of consuming salt is not optimum. The objectives of the research are: 1) to analyze the potential production of consuming salt in the study area; and 2) to analyze the existing production of consuming salt in the study area. The research uses descriptive approach. The data consist of primary data and secondary ones. Data collecting uses techniques of interview, fieldevents and document observation. The analysis uses descriptive one. There are three main findings in the research. Firstly, the potential production of consuming salt in Pati Regency is nearly 209,202 tons yearly but the existing production of consuming salt is 73,380 tons yearly, which is equal to $35.076 \%$ from the provided local potential production of consuming salt. Secondly, normatively local community in Pati Regency has consumption to salt 6,674 ton yearly, and the ekspor potential of salt is 202,527 ton yearly but the approximately annual salt ekspor is 66,706 ton because the realized production is not optimum. Thirdly, the product quality of consuming salt in the study area is under standard in general because of under standard raw materials and under standard equipments for production.
\end{abstract}

Keywords: existing production, consuming salt, potential production

\begin{abstract}
ABSTRAK
Kabupaten Pati memiliki potensi produksi garam sangat besar tetapi ada indikasi realisasi produksi garam konsumsi belum optimal. Penelitian ini bertujuan untuk: 1) Menganalisa potensi produksi garam konsumsi di area studi; dan 2) Menganalisa eksistensi produksi garam konsumsi di area studi. Penelitian ini menggunakan pendekatan deskriptif. Data penelitian meliputi data primer dan data sekunder. Pengumpulan data menggunakan teknik wawancara, observasi lokasi (fieldevents) dan observasi dokumen. Analisis data menggunakan analisis deskriptif. Penelitian ini memiliki 3 temuan utama. Pertama, potensi produksi garam konsumsi di Kabupaten Pati sebanyak 209.202 ton per tahun tetapi realisasi produksi hanya sebesar 73.380 ton per tahun $(35,076 \%)$ dari total potensi yang tersedia. Kedua, secara normatif konsumsi masyarakat domestik terhadap garam konsumsi di Kabupaten Pati sebesar 6.674 ton/tahun, dan daerah ini memiliki potensi ekspor garam konsumsi sebanyak 202.527 ton per tahun tetapi realisasi ekspor garam konsumsi hanya sebesar 66.706 ton per tahun karena realisasi produksi yang tidak optimal. Ketiga, kualitas produksi garam konsumsi di area studi umumnya di bawah standar dikarenakan faktor bahan baku yang kurang baik dan proses produksi yang tidak memiliki sarana/prasarana yang memadai.
\end{abstract}

Kata kunci: eksistensi produksi, garam konsumsi, potensi produksi 


\section{PENDAHULUAN}

Kabupaten Pati memiliki potensi produksi garam sangat besar tetapi ada indikasi realisasi produksi garam konsumsi belum optimal. Kondisi produksi garam konsumsi umumnya berkualitas kurang baik sehingga realisasi produksi kurang optimal dan daya saing produk garam konsumsi relatif lemah. Terkait dengan kualitas garam konsumsi, Ngargono (2012) menyatakan bahwa sekitar $70 \%$ dari 92 industri garam di Jawa Tengah tidak memenuhi standar yodium yang telah ditetapkan pemerintah. Kondisi ini dikhawatirkan merugikan konsumen, terutama anak-anak karena berdampak pada kesehatan, mulai dari mutasi gen, menghambat pertumbuhan, hingga cacat mental. Kondisi ini tidak dapat dilepaskan dari kualitas produksi garam beryodium di Kabupaten Pati karena daerah ini merupakan penghasil garam terbesar di Jawah Tengah.

Mirandati (2007), menyatakan bahwa Kabupaten Pati sebagai penghasil garam terbesar di Jawa Tengah tetapi daerah ini masuk daerah endemis GAKI tertinggi. Hal ini terjadi karena garam yang diproduksi belum memenuhi syarat mutu SNI, yakni kadar yodium antara 30$80 \mathrm{ppm}$. Berdasarkan hasil survei periode 2000-2006, diketahui bahwa dari 43 perusahaan/produsen garam di Kabupaten Pati, yang produksinya memenuhi syarat mutu SNI hanya 13 produsen $(32,6 \%)$ dan lainnya, 30 industri garam beryodium $(67,4 \%)$ tidak memenuhi standar SNI. Dengan kapasitas produksi terbanyak di Jawa Tengah yakni sekitar 100.045 ton/tahun, garam dari Kabupaten Pati didistribusikan ke berbagai daerah di Jawa Tengah. Konsekuensi logisnya, dampak yang ditimbulkan akibat produksi garam konsumsi yang tidak memenuhi syarat mutu SNI tersebut juga dialami wilayah pemasaran garam rentan menjadi daerah endemis. Penelitian ini bertujuan untuk: 1) Menganalisa potensi produksi garam di area studi; dan 2) Menganalisa realisasi produksi garam konsumsi di area studi.

\section{TINJAUAN PUSTAKA}

\section{Garam Konsumsi Beryodium}

Garam beryodium menurut Badan Pengawas Obat dan Makanan (2006), adalah produk makanan untuk keperluan konsumsi rumah tangga yang komponen utamanya adalah Natrium Klorida $(\mathrm{NaCl})$ dengan penambahan Kalium Iodat (KIO3) dan memenuhi Standar Nasional Indonesia (SNI). Yodium merupakan zat gizi mikro yang dibutuhkan tubuh untuk pertumbuhan dan perkembangan fisik dan mental. Sekitar $75 \%$ dari yodium ada di dalam kelenjar tiroid yang digunakan untuk mensintesis hormon tiroksin, tetraiodotironin (T4) dan triiodotironin (T3). Yodium secara alami terdapat pada tanah dan air. Hormon-hormon tersebut sangat penting selama pembentukan embrio dan untuk mengatur kecepatan metabolis dan produksi kalori atau energi di semua kehidupan.

Yodium sangat penting untuk perkembangan dan pertumbuhan saraf otot pusat, pertumbuhan tulang, perkembangan fungsi otak, dan sebagian besar metabolisme sel tubuh kecuali sel otak. Yodium juga dibutuhkan untuk sel darah merah dan pernapasan sel serta menjaga keseimbangan metabolisme tubuh. Saluran ekskresi utama yodium adalah melalui saluran kencing (urin) dan cara ini merupakan indikator utama pengukuran jumlah pemasukan dan status yodium. Tingkat ekskresi (status yodium) yang rendah (25-20 mg $\mathrm{I} / \mathrm{g}$ creatin) menunjukan risiko kekurangan yodium dan bahkan tingkatan yang lebih rendah menunjukkan risiko yang lebih berbahaya (Brody, 1999). Daerah pegunungan umumnya kurang mengandung yodium karena terbawa aliran air, sungai, banjir, erosi dan lain-lain. 


\section{Usaha Mikro Kecil Menengah Produksi Garam}

Produksi garam di area studi umumnya masuk kategori Usaha Mikro Kecil Menengah (UMKM). Dalam konteks pembangunan sosial penyerapan tenaga kerja, Badan Pusat Statistik dalam Suhendar (2006) mengklasifikasikan industri dalam 4 kategori: 1) Industri rumah tangga, adalah industri yang jumlah karyawan/tenaga kerja berjumlah antara 1-4 orang; 2) Industri kecil, adalah industri yang jumlah karyawan/tenaga kerja berjumlah antara 5-19 orang; 3) Industri sedang atau industri menengah, adalah industri yang jumlah karyawan/tenaga kerja berjumlah antara 20-99 orang; dan 4) industri besar, adalah industri yang jumlah karyawan/tenaga kerja berjumlah 100 orang atau lebih.

Perspektif lain UU No. 20 Tahun 2008 mendefinisikan UMKM dikaitkan dengan aspek ekonomi. Pertama, Usaha Mikro adalah usaha produktif milik orang perorangan dan/atau badan usaha perorangan yang memenuhi kriteria: a) Memiliki kekayaan bersih paling banyak Rp50.000.000 (lima puluh juta rupiah) tidak termasuk tanah dan bangunan tempat usaha; atau b) Memiliki hasil penjualan tahunan paling banyak Rp300.000.000 (tiga ratus juta rupiah).

Kedua, Usaha Kecil adalah usaha ekonomi produktif yang berdiri sendiri, yang dilakukan oleh orang perorangan atau badan usaha yang bukan merupakan anak perusahaan atau bukan cabang perusahaan yang dimiliki, dikuasai, atau menjadi bagian baik langsung maupun tidak langsung dari usaha menengah atau usaha besar yang memenuhi kriteria usaha kecil. Ada dua kriteria 'Usaha Kecil' yaitu: a) Memiliki kekayaan bersih lebih dari Rp50.000.000 (lima puluh juta rupiah) sampai dengan paling banyak Rp500.000.000 (lima ratus juta rupiah) tidak termasuk tanah dan bangunan tempat usaha; atau b) Memiliki hasil penjualan tahunan lebih dari Rp300.000.000 (tiga ratus juta rupiah) sampai dengan paling banyak Rp2.500.000.000 (dua milyar lima ratus juta rupiah).

Ketiga, Usaha menengah adalah usaha ekonomi produktif yang berdiri sendiri, dilakukan oleh orang perorangan atau badan usaha yang bukan merupakan anak perusahaan atau cabang perusahaan yang dimiliki, dikuasai, atau menjadi bagian baik langsung maupun tidak langsung dengan usaha kecil atau usaha besar dengan jumlah kekayaan bersih atau hasil penjualan tahunan sesuai kriteria yang ditentukan. Ada batasan atau kriteria usaha menengah yaitu: a) Memiliki kekayaan bersih lebih dari Rp500.000.000 (lima ratus juta rupiah) sampai dengan paling banyak Rp10.000.000.000 (sepuluh milyar rupiah) tidak termasuk tanah dan bangunan tempat usaha; atau b) Memiliki hasil penjualan tahunan lebih dari Rp2.500.000.000 (dua milyar lima ratus juta rupiah) sampai dengan paling banyak Rp50.000.000.000 (lima puluh milyar rupiah).

\section{Produk Industri Berorientasi Kualitas}

Produk suatu industri bisa memasuki pasar yang lebih luas bila produk tersebut memiliki kualitas yang baik. Para ekonom sering mempopulerkan istilah manajemen kualitas terpadu (Total Quality Management). Pengertian manajemen kualitas terpadu menurut Vincent (2002) adalah suatu cara meningkatkan kinerja secara terus menerus pada setiap level operasi atau proses, dalam setiap area fungsional dari suatu usaha/organisasi dengan menggunakan semua sumberdaya manusia dan modal. Manajemen kualitas menurut Juran (1992) meliputi: perencanaan kualitas (quality planning), pengendalian kualitas (quality control), dan peningkatan kualitas (quality improvement). 
Perencanaan kualitas (quality planning) adalah penetapan dan pengembangan tujuan dan kebutuhan untuk kualitas serta penerapan sistem kualitas. Perencanaan kualitas melibatkan aktivitas sebagai berikut: 1) Identifikasi pelanggan; 2) Menentukan kebutuhan pelanggan; 3) Menciptakan keistimewaan produk yang dapat memenuhi kebutuhan pelanggan; 4) Menciptakan proses yang mampu menghasilkan keistimewaan produk dibawah kondisi operasi; dan 5) Mentransfer proses ke operasi.

Pengendalian kualitas (quality control) adalah teknik dan aktivitas operasional yang digunakan untuk memenuhi persyaratan kualitas. Pengendalian kualitas dilakukan dengan beberapa aktivitas: 1) Mengevaluasi kinerja aktual; 2) Membandingkan kondisi aktual dengan sasaran; dan (3) Mengambil tindakan atas perbedaan antara yang aktual dan sasaran.

Peningkatan kualitas (quality improvement) adalah tindakan yang diambil guna memberi nilai tambah (value added) terhadap produk untuk pelanggan. Peningkatan kualitas meliputi aktivitas: 1) Menciptakan kesadaran dan kesempatan untuk perbaikan; 2) Mengamanatkan peningkatan kualitas sebagai bagian dari setiap deskripsi pekerjaan; 3) Memberikan pelatihan cara meningkatkan kualitas; 4) Meninjau kembali kemajuan secara teratur; 5) Memberikan penghargaan kepada pemenang; 6) Mempopulerkan hasil-hasil perbaikan kualitas; 7) Memperbaiki "reward sistem" dalam perbaikan kualitas; dan 8) Mempertahankan momentum melalui perluasan rencana bisnis yang mencakup sasaran untuk peningkatan kualitas.

\section{METODE PENELITIAN}

Penelitian ini menggunakan pendekatan deskriptif. Penelitian ini memiliki lokus di Kabupaten Pati. Data penelitian meliputi data primer dan data sekunder. Pengumpulan data primer dilakukan dengan menggunakan teknik wawancara dan observasi di lokasi produksi garam (field-events). Pengumpulan data sekunder dilakukan dengan menggunakan teknik observasi dokumen instansi terkait. Analisis data menggunakan analisis deskriptif.

\section{HASIL DAN PEMBAHASAN}

\section{Analisis Potensi Produksi Garam di Kabupaten Pati}

Kabupaten Pati memiliki potensi besar untuk produksi garam. Menurut Burhanuddin (2001), Garam adalah benda padatan berwarna putih berbentuk kristal yang merupakan kumpulan senyawa dengan bagian terbesar Natrium Chlorida $(>80 \%)$ serta senyawa lainnya seperti Magnesium Chlorida, Magnesium Sulfat, Calsium Chlorida, dan lain-lain. Garam mempunyai sifat/karakteristik higroskopis yang berarti mudah menyerap air, bulk density (tingkat kepadatan) sebesar 0,80,9 dan titik lebur pada suhu $801^{\circ} \mathrm{C}$.

Kabupaten Pati memiliki produk garam terbesar dibandingkan 4 daerah lain yang memiliki potensi produksi garam di Jawa Tengah. Kabupaten Pati memiliki produk garam terbesar di Jawa Tengah terindikasi dari besarnya bantuan Program Usaha Garam Rakyat (PUGAR). Pada Tahun 2011, Pemerintah Provinsi Jawa Tengah melaksanakan Program Pemberdayaan Usaha Garam (PUGAR) dengan alokasi anggaran bantuan sebesar 14,96 miliar rupiah dengan rincian: 1) 5,785 miliar rupiah $(38,67 \%)$ di Kabupaten Pati; 2) 5,35 miliar rupiah (35,76\%) di Kabupaten Rembang; 3) 1,325 miliar rupiah $(8,86 \%)$ di Kabupaten Demak; 4) 1,25 miliar rupiah $(8,35 \%)$ di Kabupaten Jepara; dan 5) 1,25 miliar $(8,35 \%)$ di Kabupaten Brebes (Moki, 2012). Besarnya alokasi anggaran bantuan tersebut merupakan refleksi besaran produksi garam pada daerah tersebut. 
Proporsi alokasi anggaran bantuan tersebut menunjukkan bahwa Kabupaten Pati merupakan daerah penghasil garam terbesar di Jawa Tengah yang tersebar di lima kecamatan yaitu: 1) Kecamatan Batangan dengan rerata produksi sebesar $120.817,34$ ton garam per tahun; 2) Kecamatan Juwana dengan rerata produksi sebesar 37.771,31 ton garam per tahun; 3) Kecamatan Wedarijaksa dengan rerata produksi sebesar $30.567,79$ ton

garam per tahun; 4) Kecamatan Trangkil dengan rerata produksi sebesar 20.027,97 ton garam per tahun; dan 5) Kecamatan Margoyoso dengan rerata produksi sebesar 52,50 ton garam per tahun. Secara kumulatif rerata produksi garam krosok (potensi bahan baku produksi garam konsumsi) selama kurun 3 tahun terakhir (2011-20130 di Kabupaten Pati sebesar 209.201,91 ton, sebagaimana ditunjukkan Tabel 1.

Tabel 1.

Potensi Produksi Garam di Kabupaten Pati

\begin{tabular}{lccccc}
\hline \multirow{2}{*}{ Kecamatan } & Petambak & \multicolumn{2}{c}{ Produksi 2011 (ton) } & Produksi 2012 & Produksi 2013 \\
\cline { 2 - 6 } & Garam & PUGAR & Non PUGAR & PUGAR (ton) & PUGAR (ton) \\
\hline Batangan & 2.577 & $59.681,46$ & $69.051,20$ & $165.293,07$ & $68.426,29$ \\
Juwana & 1.284 & $14.867,01$ & $28.722,40$ & $47.398,45$ & $22.326,07$ \\
Wedarijaksa & 1.422 & $10.232,33$ & $25.960,00$ & $35.941,23$ & $19.569,82$ \\
Trangkil & 1.470 & $8.756,12$ & $19.373,44$ & $21.169,45$ & $10.784,90$ \\
Margoyoso & 28 & - & - & - & 52,50 \\
\hline Total Kab. Pati & 6.781 & $93.536,92$ & $143,107.04$ & $269,802.20$ & $121.159,58$ \\
\hline & & Total $(2011)=236,643.96$ & \multicolumn{2}{c}{ Rerata (ton)/tahun $=209.201,91$} \\
\hline
\end{tabular}

Sumber: Dislautkan Kab. Pati (2014)

Terkait produksi garam, bila besaran bantuan Pemerintah Provinsi Jawa Tengah untuk Program Pemberdayaan Usaha Garam (PUGAR) memenuhi prinsip keadilan dan produk garam di semua daerah yang dibantu memiliki tingkat produksi setara per satuan area (ha), maka perkiraan produksi garam di Jawa Tengah sebesar 540.938,69 ton per tahun. Besaran produk garam di Jawa Tengah tersebut didasarkan pada bantuan Kabupaten Pati sebesar 5,785 miliar rupiah $(38,67 \%)$ dari total bantuan sebanyak 14,96 miliar rupiah. Kabupaten Pati memiliki produksi garam sebesar 209.201,91 ton yang dianggap setara dengan $(38,67 \%)$ maka total produksi Jawa Tengah (100\%) sebesar sebesar 540.938,69 ton per tahun.

Kebutuhan garam nasional per tahun sebesar 1,3 juta ton (Suhendra, 2011). Pada tahun 2013 kebutuhan garam nasional tetap pada posisi kisaran 1,3 juta ton. Adam dan Budiawati (2014) menyatakan bahwa Direktur Impor Kementerian Perdagangan, Didi Sumedi, mengklaim bahwa Indonesia telah mencapai swasembada garam konsumsi pada tahun 2013. Produksi garam rakyat pada tahun 2013 sebesar 1.319.607 ton.

Produksi garam Kabupaten Pati sebanyak 209.201,91 ton per tahun yang berarti potensinya sebanding dengan $16,09 \%$ dari kebutuhan garam nasional. Penduduk Indonesia sebanyak 237.641.326 orang (BPS, 2012) dan penduduk Kabupaten Pati menurut BPS (2012) sebanyak 1.219.993. Ini berarti terdapat selisih $15,58 \%$. Berdasarkan proporsi tersebut dapat dinyatakan bahwa Kabupaten Pati memiliki potensi ekspor garam sebanyak 202.527 ton per tahun untuk mencukupi kebutuhan garam nasional. Sementara 6.674 ton digunakan untuk konsumsi masyarakat lokal Kabupaten Pati. Kondisi ini didasarkan 
pada 2 asumsi: 1) Tingkat konsumsi garam setara untuk semua penduduk di semua daerah; dan 2) Bahan baku garam di Kabupaten Pati semuanya telah

\section{Tabel 2.}

dimanfaatkan dan diolah untuk garam konsumsi.Kondisi potensi produk garam konsumsi di Kabupaten Pati ditunjukkan pada Tabel 2.

Potensi Ekspor Produksi Garam di Kabupaten Pati

\begin{tabular}{lcc}
\hline \multicolumn{1}{c}{ Potensi dan Konsumsi } & Jumlah & Proporsi (\%) \\
\hline Kebutuhan garam nasional/tahun (ton) & 1.300 .000 & 100.00 \\
Rerata produksi garam krosok Kab Pati/tahun (ton) & 209.202 & 16.09 \\
Konsumsi normatif garam Kab. Pati/tahun (ton) & 6.674 & 0.51 \\
Potensi ekspor garam Kab. Pati/tahun (ton) & 202.527 & 15.58 \\
\hline
\end{tabular}

Sumber: Pengolahan Data (2014)

\section{Analisis Eksistensi Produksi Garam Konsumsi di Kabupaten Pati}

Garam Natrium Klorida untuk keperluan masak, biasanya diperkaya dengan unsur iodin (dengan menambahkan 5 gram $\mathrm{NaI}$ per $\mathrm{kg} \mathrm{NaCl}$ ) padatan kristal berwarna putih, berasa asin, tidak higroskopis, bila mengandung $\mathrm{MgCl}_{2}$ menjadi berasa agak pahit dan higroskopis. Garam digunakan terutama sebagai bumbu penting untuk makanan, bahan baku pembuatan logam $\mathrm{Na}$ dan $\mathrm{NaOH}$ (bahan pembuatan pupuk) dan zat pengawet (Mulyono, 2009).

Kabupaten Pati memiliki 86 UMKM pengolahan garam konsumsi yang tersebar di empat kecamatan. Pertama, Kecamatan Batangan memiliki 23 usaha pengolahan garam konsumsi dengan kapasitas produksi sebanyak 2.468 ton per bulan atau setara dengan 29.616 ton per tahun. Kedua, Kecamatan Juwana memiliki 31 usaha pengolahan garam konsumsi dengan kapasitas produksi sebanyak 1.732 ton per bulan atau setara dengan 20.784 ton per tahun. Ketiga, Kecamatan Wedarijaksa memiliki 19 usaha pengolahan garam konsumsi dengan kapasitas produksi sebanyak 1.204 ton per bulan atau setara dengan 14.448 ton per tahun. Keempat, Kecamatan Trangkil memiliki 13 usaha pengolahan garam konsumsi dengan kapasitas produksi sebanyak 675 ton per bulan atau setara dengan 8.100 ton per tahun. Potensi dan realisasi produksi garam konsumsi di Kabupaten Pati ditunjukkan Tabel 3.

Tabel 3.

Potensi dan Eksistensi Produksi Garam Konsumsi di Kabupaten Pati

\begin{tabular}{lcccc}
\hline \multirow{2}{*}{ Kecamatan } & UMKM & Potensi (ton) & \multicolumn{2}{c}{ Produksi Garam konsumsi } \\
\cline { 4 - 5 } & Produsen & Bahan Baku/tahun & Jumlah (ton) & \% \\
\hline Batangan & 23 & $68.426,29$ & 29.616 & 24,513 \\
Juwana & 31 & $22.326,07$ & 20.784 & 55,026 \\
Wedarijaksa & 19 & $19.569,82$ & 14.448 & 47,267 \\
Trangkil & 13 & $10.784,90$ & 8.100 & 40,445 \\
Margoyoso & - & 52,50 & 0 & 0 \\
\hline Total & 86 & $209.201,91$ & 73.380 & 35,076 \\
\hline
\end{tabular}

Sumber: Dinas Perindustrian dan Perdagangan Kab. Pati (2014) 
Secara kumulatif produksi garam konsumsi di Kabupaten Pati sebanyak 6.115 ton per bulan atau setara dengan 73.380 ton per tahun. Realisasi produksi garam konsumsi memiliki proporsi $(35,07 \%)$ dari total potensi bahan baku yang tersedia (209.201,91 ton).
Selanjutnya, potensi ekspor garam konsumsi di Kabupaten Pati sebesar 202.527 ton per tahun. Namun perkiraan ekspor garam konsumsi hanya sekitar 66.706 ton per tahun. Potensi dan eksistensi ekspor produksi garam konsumsi ditunjukkan pada Tabel 4.

\section{Tabel 4.}

Potensi dan Eksistensi Ekspor Produksi Garam Konsumsi di Kabupaten Pati

\begin{tabular}{lcc}
\hline \multicolumn{1}{c}{ Potensi dan Realisasi } & Jumlah & Proporsi (\%) \\
\hline Kebututahan garam nasional/tahun (ton) & 1.300 .000 & 100.00 \\
Rerata produksi garam krosok Kab. Pati/tahun (ton) & 209.202 & 16.09 \\
Konsumsi normatif garam Kab. Pati/tahun (ton) & 6.674 & 0.51 \\
Potensi ekspor garam Kab. Pati (ton) & 202.527 & 15.58 \\
Realisasi produksi garam konsumsi/tahun (ton) & 73.380 & 5.64 \\
Konsumsi normatif garam konsumsi/tahun (ton) & 6.674 & 0.51 \\
Perkiraan ekspor garam konsumsi Kab. Pati (ton) & 66.706 & 5.13 \\
Selisih potensi dan realisasi ekspor garam konsumsi & 135.821 & 10.45 \\
\hline
\end{tabular}

Sumber: Pengolahan Data (2014)

\section{Eksistensi Pemasaran Produksi Garam Konsumsi}

Produksi garam rerata tiga tahun terakhir di Kabupaten Pati sebanyak 209.201,91 ton per tahun atau sebanding dengan $16,09 \%$ dari kebutuhan garam nasional. Penduduk Indonesia sebanyak 237.641.326 orang (BPS, 2012) dan penduduk Kabupaten Pati sebanyak 1.219.993 (0,513). Hal tersebut menunjukkan adanya selisih proporsi $15,58 \%$. Berdasarkan proporsi tersebut, estimasi potensi ekspor garam Kabupaten
Pati sebanyak 202.527 ton per tahun untuk mencukupi kebutuhan garam nasional. Selebihnya 6.674 ton per tahun digunakan untuk konsumsi masyarakat domestik Kabupaten Pati. Hal tersebut berdasarkan pada dua asumsi, yaitu: 1) Tingkat konsumsi garam setara untuk semua penduduk di semua daerah; dan 2) Semua bahan baku garam dari Kabupaten Pati telah dimanfaatkan dan diolah untuk garam konsumsi.

Tabel 5.

Pemasaran Produk Garam Konsumsi

\begin{tabular}{lcc}
\hline \multicolumn{1}{c}{ Pemasaran Produk Garam Konsumsi } & Jumlah & Proporsi (\%) \\
\hline Kebutuhan garam nasional/tahun (ton) & 1.300 .000 & 100,00 \\
Rerata produksi garam krosok/tahun (ton) Kab Pati & 209.202 & 16,09 \\
Konsumsi normatif Garam Kab. Pati (ton) & 6.674 & 0,51 \\
Potensi ekspor Garam Kab. Pati (ton) & 202.527 & 15,58 \\
Pemasaran garam di Jawa Tengah (30 dari 35 kab) & 30 & 85,71 \\
Pemasaran garam di Indonesia (8 dari 33 prov) & 8 & 24,24 \\
\hline
\end{tabular}

Sumber: Pengolahan Data (2014)

Kabupaten Pati memiliki 86 UMKM pengolahan garam konsumsi dengan kapasitas produksi sebesar 6.115 ton per bulan atau setara dengan 73.380 ton per tahun. Kapasitas produksi 73.380 ton per tahun setara dengan $(35,08 \%)$ dari 
potensi lokal yang tersedia 209.202 ton/tahun. Pemasaran garam konsumsi yang diproduksi di Kabupaten Pati dipasarkan ke 30 kabupaten/kota $(85,71 \%)$ di Jawa Tengah dan daerah lain di 7 provinsi di luar Jawa Tengah. Dengan kata lain pemasaran di 8 provinsi $(24,24 \%)$ dari 33 provinsi di Indonesia. Kondisi pemasaran produk garam konsumsi ditunjukkan Tabel 5.Kabupaten Pati memiliki produksi garam konsumsi sebesar 73.380 ton per tahun dan konsumsi masyarakat lokal sekitar 6.674 ton, maka garam konsumsi yang dieksport ke luar daerah sebesar 66.706 ton. Sebanyak 30 daerah di Jawa Tengah masuk pangsa pasar produksi garam konsumsi di Kabupaten Pati tetapi ada 5 daerah yang tidak masuk pangsa pasar yaitu: 1) Purbalingga; 2) Boyolali; 3) Sukoharjo; 4) Karanganyar; dan 5) Batang). Sebagian UMKM menyatakan produk pengolahan garam yang mereka miliki dipasarkan di Solo. Kabupaten Boyolali, Karanganyar dan Sukoharjo tidak ada yang menyebut sebagai daerah target pasar UMKM pengolahan garam. Namun ada potensi daerah tersebut mendapatkan garam konsumsi dari Kabupaten Pati melalui agen pemasaran di Solo (Surakarta). Selain daerah di Jawa Tengah, produk garam konsumsi dari Kabupaten Pati juga dipasarkan ke provinsi lain yang ditunjukkan Tabel 6.

Tabel 6.

Daerah Pemasaran Produk Garam Konsumsi Lintas Provinsi

\begin{tabular}{llc}
\hline \multicolumn{1}{c}{ Pasar Luar Jateng } & \multicolumn{1}{c}{ Daerah Target Pemasaran } & UMKM \\
\hline Provinsi Jawa Timur & Ngawi, Magetan, Tuban, Bojonegoro dan Surabaya & 10 \\
DIY & Yogyakarta, Gunungkidul, dan Wates & 25 \\
Jawa Barat & Bogor, Indramayu, Subang, Bandung, Ciawi, & 18 \\
& Ciamis, Purwakarta dan Bekasi & \\
DKI & Jakarta tanpa menyebut kawasan lebih jelas & 25 \\
Lampung & Tanpa menyebut daerah lebih jelas & 3 \\
Palembang & Tanpa menyebut daerah lebih jelas & 1 \\
Sumatera & Tanpa menyebut daerah lebih jelas & 2 \\
Kalimantan & Tanpa menyebut daerah lebih jelas & 2 \\
\hline
\end{tabular}

Sumber: Pengolahan Data dari Dislautkan Kab. Pati (2014)

Berdasarkan uraian tersebut di atas diketahui bahwa produk pengolahan garam konsumsi di Kabupaten Pati memiliki pasar yang tersebar hampir di seluruh daerah di Jawa Tengah dan sebagian daerah lain lintas provinsi di Indonesia.

\section{Pembahasan Produk Garam Konsumsi}

Hasil pengolahan garam konsumsi di Kabupaten Pati tidak sebesar potensi yang dimiliki. Potensi produksi garam konsumsi (bahan baku) sebesar 209.202 ton per tahun. Kondisi garam krosok Kabupaten Pati, sebagian memiliki kualitas kurang baik khususnya garam krosok yang dihasilkan oleh para penyewa tambak. Petani garam (penyewa lahan) mementingkan kuantitas produksi dibandingkan kualitas produksi. Garam yang cepat dipanen (kurang dari 1 minggu) memiliki tingkat kandungan air masih tinggi dan berpengaruh pada rendahnya kualitas produksi garam konsumsi. Pengolahan garam konsumsi di Kabupaten Pati sekitar 73.380 ton per tahun $(35,08 \%)$ dari potensi yang tersedia (209.202 ton per tahun). Dengan kata lain, secara kuantitas produksi garam konsumsi di Kabupaten Pati belum berkembang optimal.

Kemudian secara kualitas produksi garam konsumsi di daerah ini juga masih memprihatinkan. Pengolahan garam konsumsi di daerah ini umumnya masih 
sangat sederhana sehingga sulit diharapkan memenuhi Standar Nasional Indonesia (SNI) yaitu $30-80$ ppm. Terkait kualitas, ada beberapa kendala yang berkaitan dengan produksi pengolahan garam konsumsi di Kabupaten Pati. Pertama, bahan baku yang dihasilkan para petambak garam umumnya memiliki kualitas kurang baik. Sebagai contoh perbandingan, para petambak garam di Kecamatan Wedarijaksa memanen garam dari tambak pada hari ketiga atau keempat. Para petambak garam di daerah lain seperti di Jepara memanen garam dari tambak pada hari ketujuh. Ini berarti garam krosok bahan baku pengolahan garam konsumsi dari Pati memiliki kandungan air lebih tinggi. Dampaknya, kualitas yang dihasilkan relatif lebih rendah dan saat diolah menjadi garam konsumsi akan

lebih boros (inefisien) untuk percampuran yodium.

Kedua, proses produksi garam konsumsi (beryodium) umumnya menggunakan cara yang sangat sederhana termasuk proses percampuran yodium. Hasil uji garam konsumsi di Kabupaten Pati menunjukkan bahwa kandungan yodium umumnya masih dibawah ketentuan SNI yaitu antara 30 - 80 ppm. Guna kepentingan uji kualitas garam konsumsi yang diproduksi di area studi, penelitian ini mengambil sampel garam konsumsi sebanyak 11 merk yang diambil dari pasar secara acak. Hasil uji kandungan yodium menunjukkan hanya 2 merk $(18,18 \%)$ memenuhi standar SNI. Sementara 9 sampel garam konsumsi lainnya $(81,82 \%)$ tidak memenuhi SNI. Hasil uji kualitas dan komparasi kualitas garam konsumsi ditunjukkan Tabel 7.

Tabel 7.

Hasil Uji Kualitas Garam Konsumsi di Kabupaten Pati

\begin{tabular}{|c|c|c|c|c|}
\hline \multirow{2}{*}{$\begin{array}{c}\text { Sampel } \\
\text { Garam Briket Produksi Pati }\end{array}$} & \multicolumn{4}{|c|}{ Kandungan Yodium (ppm) } \\
\hline & I & II & III & Komposit \\
\hline Sampel 1 & 37,8 & 33,4 & 23,3 & 30,5 \\
\hline Sampel 2 & 8,0 & 11,6 & 10,2 & 8,7 \\
\hline Sampel 3 & 32,0 & 17,4 & 26,2 & 24,9 \\
\hline Sampel 4 & 18,9 & 21,8 & 21,8 & 23,3 \\
\hline Sampel 5 & 21,8 & 36,4 & 21,8 & 21,8 \\
\hline Sampel 6 & 14,5 & 16,0 & 15,3 & 14,5 \\
\hline Sampel 7 & - & 14,5 & 12,4 & 10,9 \\
\hline \multicolumn{5}{|l|}{ Garam Halus Produksi Pati } \\
\hline Sampel 8 & & & & 49,4 \\
\hline Sampel 9 & & & & 26,2 \\
\hline Sampel 10 & & & & 20,4 \\
\hline Sampel 11 & & & & 18,9 \\
\hline \multicolumn{5}{|c|}{ Garam Pembanding Produk luar Daerah } \\
\hline Sampel Pembanding 1 (IB) & & & & 72,7 \\
\hline Sampel Pembanding 2 (Rf) & & & & 34,9 \\
\hline
\end{tabular}

Sumber: Dinas Perindustrian dan Perdagangan Kab. Pati (2014)

Secara umum kondisi hasil uji kualitas produksi garam konsumsi yang diproduksi dari Kabupaten Pati masih jauh dari ketentuan SNI. Sebagai pembanding, diambil 2 sampel garam konsumsi yang diproduksi oleh daerah lain yaitu: 1) Garam konsumsi merk "IB"; dan 2) Garam konsumsi merk "Rf”. Dua produk garam konsumsi tersebut sudah memenuhi SNI.

Terkait perbandingan di atas dalam konsep perilaku konsumen, Menurut Sulaksana (2008), merk atau brand merupakan salah satu atribut produk yang 
dievaluasi konsumen saat membeli. Merk sebuah atribut dalam hirarki yang mesti bersaing dengan atribut-atribut lain dalam merebut perhatian konsumen. Atribut lain dalam persaingan adalah kemasan, harga, dan aspek-aspek instrinsik maupun ekstrinsik lainnya. Hasil riset pasar terdahulu menunjukkan bahwa konsumen cenderung memilih produk merk terkenal sebagai indikator kualitas. Sedangkan terhadap merk yang tidak begitu terkenal akan dipakai atribut lain dalam kompetisi, misalnya harga dan kemasan.

Berdasarkan perbandingan kualitas garam konsumsi di atas, produk garam konsumsi di area studi relatif lebih rendah dari produk garam konsumsi luar daerah. Merespon kondisi tersebut, produksi garam konsumsi di area studi sangat perlu dilakukan kontrol lebih baik. Kontrol perijinan misalnya, perlu dikaitkan dengan kepemilikan standar sarana prasarana. Kontrol proses produksi misalnya, perlu dikaitkan standar proses yang menggunakan sarana/prasarana produksi yang standar. Salah satu temuan di lapangan diantaranya, produsen tidak memiliki tempat pencucian garam karena rumah yang digunakan proses produksi bersifat semi-permanen dan sewaan dari orang lain. Pembangunan tempat pencucian garam dianggap membutuhkan investasi besar sehingga tidak efektif karena rumah tersebut bukan milik sendiri.

\section{KESIMPULAN DAN SARAN}

\section{Kesimpulan}

Penelitian ini memiliki 3 temuan terkait potensi produksi garam konsumsi. Pertama, Kabupaten Pati memiliki potensi produksi garam konsumsi sebanyak 209.201,91 ton per tahun, sebanding dengan 16,09\% dari kebutuhan garam nasional (1,3 juta ton/tahun). Kedua, Sebagian bahan baku produksi garam konsumsi dari petambak garam memiliki kualitas kurang baik, kandungan air relatif tinggi. Ketiga, Kabupaten Pati memiliki potensi ekspor garam sebanyak 202.527 ton dan konsumsi masyarakat domestik sebesar 6.674 ton per tahun.

Kemudian terkait eksistensi produksi garam konsumsi, ada 4 temuan. Pertama, Kabupaten Pati memiliki 86 UMKM pengolahan garam konsumsi dengan kapasitas produksi sebesar 6.115 ton per bulan atau setara dengan 73.380 ton per tahun atau setara $(35,07 \%)$ dari total potensi bahan baku yang tersedia (209.201,91 ton). Kedua, Secara normatif konsumsi masyarakat domestik sebesar 6.674 ton per tahun maka perkiraan realisasi ekspor garam konsumsi sebesar 66.706 ton per tahun. Ketiga, Eksistensi pemasaran garam konsumsi meliputi 30 dari 35 kabupaten/kota $(85,71 \%)$ di Jawa Tengah dan daerah lain dengan jangkauan pemasaran di 8 dari 33 provinsi $(24,24 \%)$ di Indonesia. Keempat, Kualitas produksi garam konsumsi di area studi relatif kurang baik. Berdasarkan hasil uji laboratorium dari 11 sampel produk garam konsumsi beryodium diperoleh hasil bahwa: a) Produk garam konsumsi yang memenuhi standar SNI, kandungan yodium dalam garam konsumsi antara 30 sampai 80 ppm, hanya 2 merk $(18,18 \%)$; dan b) Selebihnya, 9 sampel garam konsumsi lainnya $(81,82 \%)$ tidak memenuhi standar SNI.

\section{Saran}

Produksi garam konsumsi memiliki proporsi $35,07 \%$ dari potensi lokal yang tersedia. Merespon kondisi ini, pemerintah daerah melaui dinas/instansi teknis dapat melakukan optimalisasi melalui langkah: a) Mendorong usaha pengolahan garam konsumsi agar meningkatkan produksinya; b) Melakukan pendampingan kepada petani tambak garam untuk menghasilkan bahan baku produksi garam konsumsi yang berkualitas baik; dan c) Mengundang investor untuk berinvestasi dalam pengolahan garam konsumsi. 
Produksi garam konsumsi di area studi secara umum memiliki kualitas yang relatif rendah dibandingkan dengan produk garam konsumsi dari daerah lain di pasaran. Kebijakan pemerintah daerah agar diarahkan pada: a) Penetapan standar perijinan pengolahan garam konsumsi, berkaitan dengan sarana/prasarana yang wajib dimiliki pengusaha; b) Pengawasan terhadap produksi pengolahan garam konsumsi agar menggunakan standar sarana yang memadai; dan c) Pemberlakuan sanksi yang jelas bagi usaha pengolahan garam konsumsi yang tidak memenuhi standar input (sarana/prasarana) dan standar proses

\section{DAFTAR PUSTAKA}

Adam, M., Budiawati, A. D. 2014. Indonesia Swasembada Garam Konsumsi.

(http://bisnis.news.viva.co.id/., diakses 4 Maret 2015).

Badan Pengawas Obat dan Makanan. 2006. Penentuan Kadar Spesi Yodium dalam Garam Beryodium dan Makanan dengan Metode HPLC Pasangan Ion. Jakarta: Info POM Vol. 7, No. 3, Mei 2006.

Badan Pusat Statistik. 2012. Penduduk Indonesia Menurut Provinsi. Jakarta.

Badan Pusat Statistik Provinsi Jawa Tengah. 2012. Kepadatan Penduduk Indonesia Jawa Tengah. Semarang.

Brody, T. 1999. Nutritional Biochemistry Second Edition. California: Academic Press

University of California.

Burhanuddin. 2001. Strategi Pengembangan Industri Garam di Indonesia. Yogyakarta: Kanisius.

Burhanuddin. 2001. Proceeding Forum Pasar Garam Indonesia. Jakarta: Badan Riset Kelautan dan Perikanan.
Juran, J. M. 1992. Total Quality Management: A Practical Guide. Connecticut: Juran Institute Inc.

Mirandati, D. A. 2007. Implementasi Kebijakan Pengadaan Garam beryodium di Kecamatan Batangan Kabupaten Pati. Unpublished. Prodi Magister Ilmu Administrasi. Semarang: Universitas Diponegoro.

Moki. 2012. Usaha Garam di Jawa Tengah Terus Dikembangkan. (http://www.kabarinvestigasi.com/, diakses 9 Februari 2013).

Mulyono. 2009. Membuat Reagen Kimia di Laboratorium. Bandung: Bumi Aksara.

Ngargono. 2012. Tujuh Puluh Persen Garam di Jateng Langgar Standar Yodium. Tempo, 16 Oktober 2012. (http://id.berita.yahoo.com/70persen-garam-di-jateng-langgarstandar-yodium-044604313.html)

Suhendar, Y. 2006. Bisnis Kecap Segurih Rasanya. Jakarta: Agrina.

Suhendra. 2011. Indonesia Sulit Produksi 1,3 Juta Ton Garam Anti Gondok. Detik Finance, 31 Juli 2011.

Sulaksono, U. 2008. Atribut Merek dalam Proses Evaluasi Pembelian Konsumen. (http://uyungs.wordpress.com/, diakses 12 Februari 2012).

Undang-Undang Nomor 20 Tahun 2008 Tentang Usaha Mikro, Kecil dan Menengah.

Vincent. 2002. Total Quality Management. Jakarta: PT Gramedia Pustaka Utama.

\section{BIODATA PENULIS}

Suroso, lahir 19 Maret 1966 di Kabupaten Pati Jawa Tengah. Magister Perencanaan Kota dan Daerah Universitas Gajah Mada. Bekerja di Kantor Penelitian dan Pengembangan Kabupaten Pati sebagai Peneliti Madya. 